\title{
UNSETTLING SETTLER NARRATIVES OF THE PAST
}

\author{
Transforming Cultures eJ ournal, \\ Vol. 3 No 1, February 2008 \\ http:// epress.lib.uts.edu.au/journals/TfC
}

\section{Lindi Renier Todd ${ }^{1}$}

Rethinking Settler Colonialism. History and Memory in Australia, Canada, Aotearoa New Zealand and South Africa, 2006, edited by Annie E. Coombes. Manchester University Press, Manchester and New York. ISBN: 0-7190-7168-2 (hardcover); (xiii \& 274 pages).

\section{Introduction}

This edited collection of 13 essays represents the newest addition to the 'Studies in Imperialism' series which, as the general editor John MacKenzie explains is concerned with "notions of dispossession and repossession," particularly focusing on "the effects of dismembering and remembering the past upon perceptions in the present" (MacKenzie: p. xii). The volume is positioned as a tool for allowing those who have been displaced and marginalised as a result of colonial policies, to better understand the historical context of their situation and so strengthen their claims for greater political representation and autonomy in the present. Coombes insists that:

“... an understanding of the political and cultural institutions and practices which shaped these colonial societies in the past can provide important insights into the available means for contesting its legacy of unequal rights by historically marginalized peoples in the present” (Coombes: p. 2).

Reading the volume now is, therefore, especially timely both in the context of the momentous decision by the Australian Prime Minister Kevin Rudd's government to issue a parliamentary apology to the stolen generations (13 February 2008) to "remove a

\footnotetext{
${ }^{1}$ Lindi Todd is an anthropologist whose recent doctoral work has included researching Afrikaner identifications in post-apartheid, in the wake of the Truth and Reconciliation Commission South Africa. She works as Research and Publications Officer for Transforming Cultures Research Centre.
} 
blight on the nation's soul", 2 and at a time in which academics, community representatives, policy makers and grassroots activists have been debating the previous government's contentious policy decisions re the Northern Territory intervention passed in the light of the "Little Children Are Sacred” report, 2007. ${ }^{3}$

The volume is intended to un-settle settler narratives of the past. As Proudfoot (2007) indicates, the key issues haunting the pages of this work relate to questions of collective responsibility, of how the collective and 'imagined' histories of the past are represented and if the past demands moral judgement. It is also intended to unsettle disciplinary boundaries by drawing together transnational and comparative social and cultural histories, together with personal reflection and more 'mainstream' historical research. ${ }^{4}$ These are both themes which also make this book of particular relevance for review in the Landscapes of Meaning edition of the Transforming Cultures eJournal: drawing as it does on a conference which brought together academics, grass-roots activists and community representatives from both Australia and the Indian subcontinent, to facilitate cross-disciplinary discussion and further future research networks. Furthermore, like Rethinking Settler Colonialism, the conference explored what light could be shed on different perspectives through comparison and has drawn these together using a variety of styles of presentation which includes the 'conversations' section in this edition.

\section{Aim and structure of the book}

Rethinking Settler Colonialism chooses to focus on settler colonialism in Australia, Aotearoa New Zealand, Canada and South Africa. The book is described as furthering comparative research between these sites with some contributors attempting crosscultural and intra-national comparisons (Gillian Whitlock, Nicholas Thomas, Christine Boyanoski, Elizabeth Furniss). The majority of the papers, however, concentrate on single national sites, but are drawn together under four subheadings which Coombes

\footnotetext{
2 "We need to act", Sydney Morning Herald, February 10, 2008 (accessed online, 10 February 2008) at: $<$ http://www.smh.com.au/news/national/we-need-to-act-rudd/2008/02/10/1202578582163.html>.

“3 “Ampe Akelyernemane Meke Mekarle, 'Little Children are Sacred”, Report of the Northern Territory Board of Inquiry into the Protection of Aboriginal Children from Sexual Abuse, Rex Wild \& Patricia Anderson, April 2007, Northern Territory Government. Available online: $<$ http://www.nt.gov.au/dcm/inquirysaac/>

${ }^{4}$ It joins other recent edited volumes examining settler colonialism including Elkins and Pedersen (2005) and Curthoys (2005).
} 
insists "encourages a dialogic relation between contributions within each thematic section" (p. 3). These subsections are organised around the themes of examining colonial institutions and practices; the ordering of culture through museum and monuments; engagement and resistance; and finally new subjectivities and the politics of reconciliation.

Coombes is quick to point out that the volume does not concentrate solely on similarities of historical experience of settler communities despite what she maintains are their "shared familiarity with cultural and political institutions, practices and policies” (p. 1) as a result of their developing largely from the effects of British colonisation. Indeed, it is intended to make clear the influence of the particular - in terms of the local encounters with indigenous peoples with different political, cultural and social structures as well as the heterogeneous nature of the first colonisers and settlers - on the different forms that the settler nations came to take.

The strength of the volume lies in the diversity of disciplinary perspectives which are drawn together across a wide range of material and styles of engagement. Emphasising this intention, the volume begins with what are called Artists' Pages "Facing history”. Photographic images from three multimedia artists and film makers (Brook Andrew from Australia, Lisa Reihana from New Zealand, whose work forms the cover illustration for the volume and Berni Searle from South Africa) play with representations of hybrid and "authentic" identity formation. Readers have to rely on Coombes' introduction as a background illustration of their work and I for one, would have liked to have read something of the artists' own interpretations and words here which would have added to the strength of the cross-disciplinary innovation of including them in this volume. Nevertheless, the images disturb our sense of the apparent straightforwardness of classification and identification and provide an interesting introduction to some of what is to come in the discussion ahead.

For Coombes, the term 'settler' has benign overtones which has problematically hidden within it the violence of colonial encounters which have transformed indigenous peoples through what she insists have been "consistently discriminatory and genocidal regimes” (p. 2). This issue lies at the heart of the first paper of the volume: Gillian Whitlock's account of child removal policies practiced in Australia and Canada. 
Whitlock examines the similarities and differences in experience of what has come to be referred to as the 'stolen generation' in Australian (brought to general public attention through the Bringing Them Home Report ${ }^{5}$ ) and Canadian assimilation policies (particularly focusing on Indian Residential Schools) concerned with child welfare, both of which involved child removal. Although careful not to generalise a point of origin for these policies, she draws out the similarities of response in the present, especially focusing on the use of testimonial for discursive justice. Although she agrees with Barkan (2000) in seeing the growing emphasis on testimony as part of a global process, fuelled by the work of the Truth and Reconciliation Commission (TRC) in South Africa, she does emphasise that in the particular context of settler colonialism, indigenous testimony has given new impetus to settler memoir. For Whitlock, memoir and testimony "play out the fraught relationality and desire for the closure of belonging which is the irreconcilable legacy of invasion and settlement” (p. 42).

This desire to belong and process of negotiation involved is a theme which the volume returns to throughout. Similarly in the final chapter of the book, Sarah Nuttall writes from within South Africa, focusing specifically on the complex position of the settler. She introduces into the discussion what she sees as a shift in the meaning of the term 'settler'. Like Coombes, she recognises that the notion has contained within it masterslave relationships based on conquest, ownership, dispossession and subjugation. But this, she argues, has shifted in the wake of the TRC to encompass the process of negotiating a space to belong. She eloquently describes this moment as a "move from the politics of conquest and subjugation to the politics of negotiation and belonging” (p. 245-246).

Whereas Whitlock was concerned with analysing the impact of harnessing memoir and testimony for a politics of reconciliation, Nuttall provides a reading of memoirs and autobiographies written by prominent South African anti-apartheid activists (Ruth First and Joe Slovo) and writers (Gillian Slovo, Antjie Krog and JM Coetzee) for what they tell us about 'whiteness' in the context of subscribing to non-racialism, including the

\footnotetext{
5 "Bringing Them Home. National Inquiry into the Separation of Aboriginal and Torres Strait Islander Children from their Families” (1997) Human Rights and Equal Opportunity Commission Report. Available online: <http://www.hreoc.gov.au/social_justice/bth_report/index.html> (accessed February 2008).
} 
complex set of relationships they express in relation to their country of birth in the context of rejecting its violent past.

In addition to settler-indigenous encounters, Coombes had noted the complex relationship between "white settler communities" and the "British metropolitan imperial centre” which in turn affected their interactions with the indigenous communities they encountered (p. 3). Leslie Witz's paper looks at the position of a trade union in South Africa representing class-based interested in the growing onslaught of Afrikaner Nationalists to emphasise issues of race. Through examining the response of the Garment Workers' Union to two commemorative events (the centenary of the Great Trek and 300 year celebration of the arrival of Jan van Riebeeck in South Africa) Witz documents the contests and struggles involved in the process of defining the ethnic identity of Afrikaner as originating in a past involving the struggle for freedom, which was ultimately to lead in 1948 to the election success of the National Party.

Issues of belonging and negotiating a sense of place also form the focus of Parvathi Raman's paper, "Being Indian the South African Way". She adds a further level of complexity to the triangle of colonial-indigenous-metropolitan relations marked out by Coombes, to include that of the position of the non-indigenous, migrants and indentured labourers from India and their attempts to negotiate a space of belonging in the country of their birth in response to growing racial discrimination and in response to black South African 'others'. Raman traces the influence of ideas (Gandhi's satyagraha) on assertions of Indian identity and the growing distance of the Indian subcontinent on their thinking, as they worked to establish themselves as Indian-South Africans.

Central to Raman's analysis, therefore, is what she talks about as "an act of political and cultural translation” (p. 202) through which the notion of Indianness comes to draw on the discourse of imperial brotherhood, Indian nationalism and idealised tradition, in combination with a sense of belonging in South Africa (p. 194). This interest in finding ways of speaking, of being heard and resisting representation is shared in the papers by Furniss and Paisley.

Elizabeth Furniss looks at discussions of colonial settler history by indigenous and non-indigenous people, comparing two sites in Canada and Australia. She examines 
how the past which has been founded on frontier symbolism and narratives in both resulting in a particular historical consciousness which she terms the 'frontier complex' (p. 182) - has been or can be resisted and subverted by indigenous populations. Her investigations reveal that the inability to speak, or silence (as deliberative, repressive or traumatic) need to be recognised for what they reveal about factors enabling narration and consequently the processes by which it can be destroyed and subsequently be rebuilt.

Fiona Paisley's paper traces the life and travels of an extraordinary Aboriginal man, Anthony Martin Fernando, as he campaigns abroad for Aboriginal rights in the late $19^{\text {th }}$ to early $20^{\text {th }}$ century. She documents how the authorities respond to him, his persistence in getting his voice heard and his self-identification with the transnational black community in Europe.

Questions of agency of self-representation, speech or silence, appropriation and objectification are at the heart of the rest of the chapters in the volume. Following on from her interest in the politics of representation and contestation of national histories in and around public displays in museums and monuments as demonstrated in previous work (1994, 2003) Coombes has insisted on situating cultural practices and institutions at the centre of analyses of settler-indigenous relations in this volume once again. This provides the theme for Martin Legassick's paper on how 'Bushmen' became confined and exhibited in the Northern Cape (South Africa), and continues for the largest subsection of the book, namely Part II, 'The ordering of culture: new nations for old'.

Paul Tapsell leads this section, reflecting on his experiences as museum curator and speaking as a person of Te Arawa and Tainui descent, he discusses Maori identity complexity and the ethnic contests which have resulted in the misinformed propensity to unite them all under a single racially biased banner with implications for future miscommunication and insult. Whereas Legassick's paper talked of the appropriation and objectification of indigenous people for display by museums in the early $19^{\text {th }}$ and $20^{\text {th }}$ centuries, Tapsell urges us to consider how local people can be involved in national museums at a governance level, to further indigenous agency in their own selfrepresentation. 
Leonard Bell and Nicholas Thomas both examine the changing values and meanings ascribed to historical artefacts. Bell focuses on a monument (Cornwall Park and the One Tree Hill Summit Monument) in Auckland, which he contends has become "an unstable terrain of conflicting meanings and viewpoints" (p. 116). Interpretations of monuments should not be simplified, he warns, as "[l]andscape, art and artefacts emerge as a site of interacting forces and tensions that disallows any singularity of meaning and effect” (p. 102). For Thomas, the focus is on the changing figure of Captain Cook and how his encounters with Aboriginal Australians and Maori have been imagined and re-imagined.

Returning to Canada, Ruth B. Phillips examines four major exhibitions of indigenous art and the contestations surrounding each, which she argues are able to reveal broader relationships between 'show times' (which she suggests are when definitive and comprehensive exhibitions are organised to connect to major events in the life of a community) and the formation of national policy. She doesn't suggest a simple cause and effect relationship, but persuasively suggests that "the ritual performances that take place at show times are interrelated in complex ways with larger political dynamics” (p. 136).

Examining another event which resulted in the heightened visibility of settler selfrepresentation, Christine Boyanoski examines the British Empire Exhibition of 1924 in Wembley, England. Drawing comparisons with Raman’s focus on political and cultural translation, Boyanoski demonstrates how representatives from Canada, Australia, South Africa, New Zealand and India struggled to find a representative national cultural identity to present at the exhibition: trapped between working within the bounds of imperial expectations and exhibition criteria determining acceptable visual art representations, and creating a sense of their identities as independent from the Empire's constraints.

Finally, in a reflective piece analysing the landscape stories presented along the Oregon Trail (USA) and narratives of settlers and place in the National Museum of Australia, Canberra (Australia) Deborah Bird Rose brings us full circle to face the question of accountability and the role that apology should play in addressing the legacy of settler colonialism. She ends by proclaiming that "I find myself profoundly moved towards the 
idea that 'sorry' is a magnificently dense place in which to position the work of decolonisation” (p. 242).

Out of the four chosen sites discussed in the volume, Australia's government is the most recent to choose to make a formal apology to its indigenous people for policy decisions taken in the past, ${ }^{6}$ and so leaves behind the legacy of the previous Federal government's refusal: a decision which Whitlock suggested then, "appear[ed] to have the support of the majority of the population” (p. 26). It remains to be seen how the country will move forward from its current moment of euphoria. But if we return to one of Coombes' central points in Rethinking Settler Nations, settler nations are shaped by their dealings with indigenous peoples. We can anticipate, therefore, that this shift in government response to the past will continue to "mediat[e] in highly significant ways their shared colonial roots/routes” (p. 1-2).

\section{References}

"Bringing Them Home. National Inquiry into the Separation of Aboriginal and Torres Strait Islander Children from their Families” (1997) Human Rights and Equal Opportunity Commission Report. Available online: $<$ http://www.hreoc.gov.au/social_justice/bth_report/index.html $>$ (accessed February 2008).

Barkan, E. (2000) The Guilt of Nations: Restitution and Negotiating Historical Injustices, W.W. Norton, New York.

Bayly, C.A., Beckert, S., Connelly, M. Hofmeyer, I., Kozol, W. \& Seed, P. (2006) "AHR Conversation: On Transnational History", The American Historical Review, Vol. 111, Issue 5:

Coombes, A.E. (1994) Reinventing Africa: museums, material culture, and popular imagination in late Victorian and Edwardian England, Yale University Press, New Haven.

Coombes, A.E. (2003) History After Apartheid: visual culture and public memory in a democratic South Africa, Duke University Press, Durham.

Curthoys, A \& Lake, M. (eds.) (2005) Connected Worlds. History in Transnational Persepective, ANU ePress.

Elkins, C. \& Pedersen, S. (2005) Settler Colonialism in the Twentieth Century. Projects, Practices, Legacies, Routledge, New York and London.

Goodall, H. (2008) “Introduction”, Landscapes of Meaning...Transforming Cultures eJournal, Vol. 3(1).

\footnotetext{
${ }^{6}$ Prime Minister Kevin Rudd's “Apology to Australia’s Indigenous Peoples”, can be accessed online here $<$ http://www.aph.gov.au/house/index.htm>.
} 
Minister of Indian and Northern Affairs (7 January 1998) 'Statement of Reconciliation', Indian and Northern Affairs, Canada. Available online: <http://www.aincinac.gc.ca/gs/rec_e.html> (Accessed February 2008).

Proudfoot, L. (2007) Review, Journal of Historical Geography

Rudd, Prime Minister Kevin (13 February 2008) “Apology to Australia’s Indigenous Peoples”, available online here <http://www.aph.gov.au/house/index.htm> (accessed February 2008). 